\title{
PENGARUH PENGGUNAAN ENCENG GONDOK (Eichornia crassipes) TERFERMENTASI DALAM RANSUM TERHADAP PERSENTASE KARKAS, NON-KARKAS, DAN LEMAK ABDOMINAL ITIK LOKAL JANTAN UMUR DELAPAN MINGGU
}

\section{THE EFFECT OF FERMENTED Eichornia crassipes SUPPLEMENTATION IN THE DIET ON THE PERCENTAGE OF CARCASS, NON-CARCASS AND ABDOMINAL FAT OF EIGHT WEEK OLD LOCAL MALE DUCK}

\author{
Ratih Dewanti*, Muhammad Irham, dan Sudiyono \\ Jurusan Peternakan, Fakultas Pertanian, Universitas Sebelas Maret, Jl. Ir. Sutami 36a, Kentingan, Surakarta, 57126
}

\section{INTISARI}

Penelitian ini dilakukan untuk mengetahui pengaruh penggunaan enceng gondok terfermentasi terhadap bobot potong, bobot karkas, persentase karkas, non-karkas, dan lemak abdominal. Penelitian dilakukan dengan menggunakan Rancangan Acak Lengkap (RAL) pola searah. Perlakuan meliputi: P0 (ransum basal); P1 (ransum basal $+2,5 \%$ enceng gondok terfermentasi); P2 (ransum basal $+5 \%$ enceng gondok terfermentasi); P3 (ransum basal $+7,5 \%$ enceng gondok terfermentasi); dan P4 (ransum basal $+10 \%$ enceng gondok terfermentasi). Hasil penelitian dari kelima perlakuan diperoleh nilai rerata bobot potong $1261,97 \mathrm{~g}$; persentase karkas 53,22\%; persentase sayap 16,03\%; paha 28,68\%; dada $20,58 \%$, dan punggung $24,71 \%$. Rerata persentase non-karkas berturut - turut adalah kepala $15,22 \%$; kaki $2,68 \%$; hati $2,21 \%$; jantung $0,72 \%$; empedal $4,74 \%$; dan lemak abdominal $0,63 \%$. Hasil penelitian menunjukkan bahwa penambahan enceng gondok terfermentasi dalam ransum sampai tingkat $10 \%$ tidak berpengaruh terhadap bobot potong, persentase karkas, non-karkas, dan lemak abdominal itik lokal jantan umur delapan minggu.

(Kata kunci: Itik lokal jantan, Enceng gondok terfermentasi, Karkas, Non-karkas, Lemak abdominal)

\section{ABSTRACT}

The research was aimed to observe the effect of fermented Eichornia crassipes on slaughter weight, carcass weight, percentages of carcass, non-carcass and abdominal fat of 8 weeks old male ducks. The research design was one way Completely Randomized Design (CRD). The treatment included: P0 (basal diet); P1 (basal diet $+2.5 \%$ fermented Eichornia crassipes), P2 (basal diet $+5 \%$ fermented Eichornia crassipes), P3 (basal diet $+7.5 \%$ fermented Eichornia crassipes), P4 (basal diet $+10 \%$ fermented Eichornia crassipes). The results of the five treatments showed that the mean value of the slaughter weight was $1261.97 \mathrm{~g}$, the carcass weight was $53.22 \%$, the wing weight was $16.03 \%$, the thigh weight was $28.68 \%$, the breast weight was $20.58 \%$, and the back weight was $24.71 \%$. Mean of the non-carcass percentage was respectively $15.22 \%$ (head), 2.68\% (shank), $2.21 \%$ (liver), $0.72 \%$ (heart), 4,74\% (gizzard) and the percentage of abdominal fat was $0.63 \%$. The results showed that the use of fermented Eichornia crassipes in the diet up to level $10 \%$ has no effect on the slaughter weight, carcass, non-carcass and abdominal fat percentage of eight week old local male ducks.

(Keyword: Local male ducks, Fermented Eichornia crassipes, Carcass, Non-carcass, Abdominal fat)

\section{Pendahuluan}

Daging merupakan salah satu sumber protein hewani yang dapat diandalkan untuk pemenuhan sumber gizi. Pengembangan usaha ternak itik diperlukan sebagai salah satu sumber penghasil daging. Usaha ternak itik lokal memberikan potensi yang cukup baik untuk dikembangkan sebagai penghasil daging. Itik yang dipelihara untuk tujuan produksi daging dapat diperoleh dari peternakan itik pedaging, itik petelur dan itik jantan (Windhyarti, 2002). Pemeliharaan itik lokal jantan mulai dari Day Old Duck (DOD) sampai umur potong hanya

\footnotetext{
* Korespondensi (corresponding author):

Telp. +62 85229713111

E-mail: dewa_proter@yahoo.com
}

memerlukan waktu selama delapan minggu. Pemeliharaan itik pedaging memiliki tujuan pokok untuk memenuhi kebutuhan daging bagi konsumsi manusia. Kandungan gizi daging itik hampir sama dengan daging ayam, bahkan kandungan lemaknya lebih tinggi, sehingga energinya pun lebih tinggi (Srigandono, 1997).

Pakan merupakan salah satu faktor penting yang akan menentukan keberhasilan usaha peternakan. Tinggi rendahnya nilai suatu bahan pakan ditentukan oleh kualitas dan kuantitas nutrien yang terkandung di dalamnya. Pertumbuhan itik lokal jantan akan lebih optimal apabila didukung dengan pakan yang baik. Salah satu usaha yang dapat dilakukan adalah dengan memberikan pakan tambahan. Pakan tambahan dicampurkan dalam ransum untuk meningkatkan metabolisme tubuh, 
menghasilkan pertumbuhan yang lebih baik dan produksi yang diinginkan (Wahyu, 1985).

Enceng gondok adalah tumbuhan air yang sering merusak lingkungan danau dan sungai, dapat menyumbat saluran irigasi, mempercepat hilangnya air, mencemari area penangkapan ikan. Enceng gondok tumbuh dengan cepat, sehingga diperlukan upaya untuk menanganinya agar tidak mengganggu dan merusak lingkungan. Salah satu alternatifnya adalah dimanfaatkan sebagai bahan pakan ternak (Mangisah et al., 2009). Pemanfaatan enceng gondok sebagai tanaman pakan belum banyak digunakan (inkonvensional) masyarakat, sedangkan pertumbuhan dan ketersediaannya sangat memadai pada musim kemarau maupun musim hujan. Komposisi nutrien enceng gondok yang dianalisis di Balai Penelitian Perkebunan Bogor menunjukkan kandungan protein kasar $13,03 \%$, serat kasar 20,16\%, kalsium (Ca) 3,09\%, fosfor (P) 0,45\%, lemak $1,1 \%$, bahan ekstrak tanpa nitrogen (BETN) $25,98 \%$, dan abu 23,87\% (Soeharsono, 1979).

Pemanfaatan enceng gondok sebagai ransum ternak memiliki beberapa kelemahan antara lain, kadar air terlalu tinggi, protein kasar, dan BETN yang sukar dicerna. Kelemahan tersebut dapat mengganggu palatabilitas dan kecernaannya, sehingga dalam pemanfaatannya harus diolah terlebih dahulu dalam bentuk fermentasi. Menurut Bidura et al. (2005) fermentasi oleh mikrobia mampu mengubah makromolekul komplek menjadi molekul sederhana yang mudah dicerna oleh unggas dan tidak menghasilkan senyawa kimia beracun.

Berdasarkan uraian tersebut, maka penelitian ini dilakukan untuk mengetahui sejauh mana enceng gondok terfermentasi dapat dimanfaatkan untuk ransum itik lokal jantan dan pengaruhnya terhadap persentase karkas, non-karkas, dan lemak abdominal.

\section{Materi dan Metode}

Penelitian dilaksanakan selama delapan minggu menggunakan 100 ekor DOD jantan berasal dari Kecamatan Sawit, Kabupaten Boyolali, Jawa Tengah.

Dua puluh petak kandang beralas (litter) dengan ukuran $1,0 \times 1,0 \times 0,5$ meter digunakan dalam penelitian ini dan setiap petak berisi lima ekor itik. Bahan untuk sekat tiap kandang terbuat dari bambu dan untuk litter dari sekam dengan ketebalan $5 \mathrm{~cm}$. Tempat pakan dan minum, termometer, lampu pijar, dan timbangan.

Pembuatan enceng gondok terfermentasi meliputi: enceng gondok dipotong, untuk penyeragaman umur dan batang dan daun dipanen setelah berumur 30 hari. Daun dan batang dipotong dengan ukuran kurang lebih $0,3 \mathrm{~cm}$ dan dikeringkan dengan sinar matahari. Potongan enceng gondok kering dimasukkan ke dalam plastik dengan ketebalan $10 \mathrm{~cm}$, kemudian starbio dan molasses ditaburkan di atasnya. Potongan enceng gondok ditumpuk di atas tumpukan sebelumnya, starbio dan molasses ditabur kembali dan seterusnya sampai plastik terisi penuh, kemudian ditutup rapat. Proses pemeraman dilakukan selama 21 hari.

Penelitian ini dilakukan secara eksperimental dengan menggunakan Rancangan Acak Lengkap (RAL) pola searah. Pakan perlakuan yang digunakan dalam penelitian terdiri dari: ransum basal (P0); ransum basal $+2,5 \%$ enceng gondok

Tabel 1. Kandungan nutrien bahan pakan untuk ransum perlakuan (the nutrient content of the treatment diet ingredients)

\begin{tabular}{|c|c|c|c|c|c|c|}
\hline Bahan pakan (feedstuffs) & $\begin{array}{c}\mathrm{ME} \\
(\mathrm{kcal} / \mathrm{kg}) \\
(\text { energy } \\
(\mathrm{kcal} / \mathrm{kg}))\end{array}$ & $\begin{array}{l}\text { Protein kasar } \\
(\%)(\text { crude } \\
\text { protein }(\%))\end{array}$ & $\begin{array}{l}\text { Serat kasar } \\
(\%)(\text { crude } \\
\text { fiber }(\%))\end{array}$ & $\begin{array}{l}\text { Lemak } \\
\text { kasar }(\%) \\
(\text { crude fat } \\
(\%))\end{array}$ & $\begin{array}{l}\mathrm{Ca}(\%) \\
(\text { calcium } \\
(\%))\end{array}$ & $\begin{array}{c}\text { Pav (\%) } \\
\text { (available } \\
\text { phosphorus } \\
(\%))\end{array}$ \\
\hline Menir jagung (corn groats $)^{1}$ & $4001,702^{4}$ & 7,41 & 0,54 & 2,78 & 0,12 & 0,05 \\
\hline Bekatul (rice bran) ${ }^{1}$ & $1627,895^{4}$ & 9,55 & 20,47 & 4,57 & 0,12 & 0,26 \\
\hline BR1 (broiler feed $)^{2}$ & $3555,304^{4}$ & 23,86 & 5,68 & 7,95 & 1,25 & 1,02 \\
\hline Top mix (mineral mix $)^{3}$ & - & - & - & - & 45 & 35 \\
\hline $\begin{array}{l}\text { Enceng gondok } \\
\text { terfermentasi (Eichornia } \\
\text { crassipes fermented) }\end{array}$ & $1891,037^{4}$ & $15,20^{5}$ & $17,81^{5}$ & $3,33^{5}$ & $0,52^{6}$ & $0,44^{6}$ \\
\hline \multicolumn{7}{|c|}{$\begin{array}{l}\text { Hasil analisis Lab. Nutrisi dan Makanan Ternak, Jurusan/Program Studi Peternakan Universitas Sebelas Maret } \\
\text { Surakarta 2011. }\end{array}$} \\
\hline \multicolumn{7}{|c|}{${ }^{2}$ Label P.T Japfa Comfeed Indonesia. } \\
\hline \multicolumn{7}{|c|}{${ }^{3}$ Brosur PT Medion Bandung. } \\
\hline \multicolumn{7}{|c|}{${ }^{4}$ Berdasar Perhitungan Rumus Sibbald } \\
\hline \multicolumn{7}{|c|}{$\mathrm{EM}=3951+(54,4 \times \mathrm{LK})-(88,7 \times \mathrm{SK})-(40,8 \times \mathrm{K} . \mathrm{Abu})$} \\
\hline Hasil analisis Lab. Biokimia & Nutrisi, Fakı & Itas Peternakan & & $M$ & & \\
\hline
\end{tabular}


Tabel 2. Susunan ransum dan kandungan nutrien ransum perlakuan (the diet composition and the nutrient content of the treatment diet $)^{1}$

\begin{tabular}{lrrrrr}
\hline \multirow{2}{*}{ Bahan pakan (feedstuff) } & \multicolumn{5}{c}{ Perlakuan (\%) (treatment (\%)) } \\
\cline { 2 - 6 } & P0 & \multicolumn{1}{c}{ P1 } & P2 & \multicolumn{1}{c}{ P3 } \\
\hline Menir jagung (corn groats) & 27 & 27 & 27 & 27 & 27 \\
Bekatul (rice bran) & 30 & 30 & 30 & 30 & 30 \\
BR 1 (broiler feed) & 42 & 42 & 42 & 42 & 42 \\
Top Mix (mineral mix) & 1 & 1 & 1 & 1 & 1 \\
Enceng gondok terfermentasi (Eichornia crassipes & 0 & 2,5 & 5 & 7,5 & 10 \\
fermented) & & & & & \\
\hline Jumlah (total) & 100 & 102,5 & 105 & 107,5 & 110 \\
\hline Kandungan nutrien (nutrient content) & & & & & \\
ME (kcal/kg) (EM (kcal/kg) & 3062,06 & 3109,33 & 3156,61 & 3203,88 & 3251,16 \\
Protein kasar (\%) (crude protein (\%)) & 14,89 & 15,27 & 15,65 & 16,03 & 16,41 \\
Serat kasar (\%) (crude fiber (\%)) & 8,67 & 9,12 & 9,56 & 10,01 & 10,45 \\
Lemak kasar (\%) (crude fat (\%)) & 5,46 & 5,54 & 5,63 & 5,71 & 5,79 \\
Ca (\%) (calcium (\%)) & 1,04 & 1,05 & 1,07 & 1,08 & 1,09 \\
P av (\%) (available phosphorus (\%)) & 0,87 & 0,88 & 0,89 & 0,90 & 0,91 \\
\hline
\end{tabular}

${ }^{\mathrm{T}}$ Hasil perhitungan berdasarkan Tabel 1 (the calculation was based on the results of Table 1).

terfermentasi $(\mathrm{P} 1)$; ransum basal $+5 \%$ enceng gondok terfermentasi (P2); ransum basal $+7,5 \%$ enceng gondok terfermentasi (P3); dan ransum basal $+10 \%$ enceng gondok terfermentasi $(\mathrm{P} 4)$.

Data penelitian meliputi: bobot potong, bobot karkas, persentase karkas, bagian-bagian karkas, non-karkas, dan lemak abdominal. Bobot potong yaitu bobot itik yang ditimbang sebelum disembelih setelah dipuasakan selama 12 jam. Bobot karkas diperoleh dari bobot potong setelah dikurangi leher, kepala, shank dan jerohan; persentase karkas dihitung dengan cara membagi bobot karkas dengan bobot potong itik kemudian dikalikan 100\% (Sudiastra, 2001). Bagian-bagian karkas diperoleh dari membagi bagian karkas dengan bobot karkas dikalikan $100 \%$. Bagian non-karkas didapatkan dari membagi bagian non-karkas dengan bobot potong dikalikan 100\%. Lemak abdominal didapatkan dari membagi bobot lemak abdominal dengan bobot potong kemudian dikalikan $100 \%$.

Penyembelihan sampel itik dilakukan 20 kali ulangan dengan dua ekor itik untuk setiap ulangannya, sehingga keseluruhan berjumlah 40 ekor. Sebelum penyembelihan itik dipuasakan terlebih dahulu selama 12 jam untuk mengosongkan makanan dalam saluran pencernaan (Soeparno, 1994). Proses penyembelihan itik dilakukan dengan memotong arteri carotis, vena jugularis, trakea dan esofagus dengan metode secara Islami.

\section{Analisis data}

Data dianalisis dengan menggunakan analisis variansi pola searah dengan desain penelitian RAL. Apabila hasil analisis variansi menunjukkan adanya pengaruh yang nyata, dilanjutkan dengan pembandingan secara Polinomial Ortogonal untuk mengetahui level optimal antara 5 perlakuan (Sastrosupadi, 2000).

\section{Hasil dan Pembahasan}

\section{Bobot potong}

Bobot potong pada penelitian masing-masing perlakuan P0, P1, P2, P3, dan P4 berturut-turut dalam g/ekor yaitu 1220,37; 1219,50; 1251,12; 1295,00; dan 1323,87. Hasil analisis variansi menunjukkan bahwa penggunaan enceng gondok terfermentasi dalam ransum tidak berpengaruh terhadap bobot potong itik lokal.

Pemberian pakan dengan konsentrasi yang berbeda pada imbangan energi dan protein yang sama tidak berpengaruh terhadap bobot potong. Hal ini menunjukkan bahwa dengan perlakuan pakan dengan tambahan enceng gondok terfermentasi sampai taraf $10 \%$ memberikan hasil bobot potong itik lokal yang tidak berbeda. Pengaruh pakan yang dimanfaatkan sebagai faktor non genetik memberikan reaksi yang sama terhadap bobot badan. Faktor pembatas utama yang berhubungan langsung dengan nafsu makan adalah kebutuhan energi pada unggas. Semua faktor yang berhubungan dengan adanya peningkatan ataupun penurunan kebutuhan energi sangat mempengaruhi regulasi nafsu makan pada ternak unggas. Dilihat dari kuantitas, itik dengan perlakuan pakan P4 (ME 3251,16/PK 16,41) cenderung mengkonsumsi pakan lebih rendah dibandingkan itik dengan perlakuan P3, P2 dan P1 yang memiliki ME dan PK lebih rendah. Namun hasil akhir dari konsumsi pakan (secara kualitas) berupa berat badan adalah sama. Nutrien digunakan untuk mencukupi kebutuhan pokok hidup dan pertumbuhan organ serta jaringan tubuh. Bobot potong dipengaruhi oleh konsumsi ransum, 
kandungan energi, dan protein (Deaton dan Lott, 1985). Nutrien digunakan untuk mencukupi kebutuhan hidup pokok dan untuk pertumbuhan organ dan jaringan tubuh. Scott et al. (1982) menyatakan bahwa terdapat hubungan antara pertumbuhan dengan konsumsi ransum. Pertumbuhan akan meningkat seiring dengan peningkatan konsumsi ransum.

\section{Persentase karkas}

Rerata persentase karkas masing-masing perlakuan $\mathrm{P} 0, \mathrm{P} 1, \mathrm{P} 2, \mathrm{P} 3$, dan $\mathrm{P} 4$ berturut-turut adalah 53,41; 52,06; 53,66; 52,40; dan 54,55\%. Pakan dengan perlakuan enceng gondok terfermentasi sampai $10 \%$ tidak memberikan pengaruh terhadap persentase karkas. Persentase karkas merupakan perbandingan antara bobot karkas dengan bobot potong yang sering digunakan sebagai pendugaan jumlah daging pada unggas (Abubakar dan Nataamijaya, 1999). Imbangan energi dan protein yang hampir sama menyebabkan hasil akhir berupa persentase karkas tidak berbeda. Persentase karkas dipengaruhi oleh faktor kualitas ransum dan laju pertumbuhan ternak (Soeparno, 1988). Laju pertumbuhan yang ditunjukkan dengan adanya pertambahan bobot badan akan mempengaruhi bobot potong yang dihasilkan. Bobot potong akan berpengaruh pada persentase karkas yang dihasilkan. Hasil yang diperoleh menunjukkan tidak adanya perbedaan persentase karkas karena bobot potong yang dihasilkan juga tidak berbeda nyata. Menurut Kamal (1994) jika berat karkas dan persentase karkas tidak berbeda nyata disebabkan karena bobot potong juga menunjukkan hasil yang tidak berbeda nyata.

Jenis kelamin dan umur itik yang digunakan adalah sama, yaitu itik lokal jantan dengan umur potong delapan minggu, sehingga persentase karkas menjadi tidak berbeda. Hal ini didukung Lesson dan Summer (1979) cit. Soeparno (1994) menyatakan bahwa persentase karkas dipengaruhi oleh jenis kelamin dan umur potong. Komponen utama karkas adalah daging. Diduga penggunaan enceng gondok terfermentasi sampai $10 \%$ tidak mampu meningkatkan ketersediaan protein yang diperlukan untuk sintesis protein daging sehingga penambahan enceng gondok terfermentasi dalam ransum itik tidak berbeda nyata terhadap persentase karkas yang dihasilkan. Menurut Anggorodi (1995) pertumbuhan jaringan tulang dan daging sangat tergantung ketersediaan protein pakan. Protein khususnya asam amino diperlukan untuk membentuk jaringan otot daging. Hasil penelitian ini memiliki persentase karkas pada kisaran normal.

\section{Persentase bagian-bagian karkas terhadap bobot karkas}

Persentase sayap. Berdasarkan hasil analisis, perlakuan pakan dengan enceng gondok terfermentasi tidak berpengaruh terhadap persentase sayap itik lokal. Rerata persentase sayap masingmasing perlakuan $\mathrm{P} 0, \mathrm{P} 1, \mathrm{P} 2, \mathrm{P} 3$, dan $\mathrm{P} 4$ berturutturut adalah 16,$10 ; 16,53 ; 15,97 ; 15,96$; dan $15,62 \%$.

Sayap bukan merupakan bagian atau tempat deposisi otot daging yang utama sehingga perlakuan pakan belum memberikan pengaruh nyata terhadap berat sayap. Sayap lebih didominasi oleh tulang, dan deposisi lemak pada bagian sayap juga rendah sehingga pada masa pertumbuhan ini didapatkan hasil yang tidak nyata. Rerata persentase sayap dari hasil penelitian ini adalah $16,24 \%$. Berat sayap ini masih di bawah hasil penelitian Ismoyowati (1999) dengan hasil 19,98\% dan hasil penelitian Dewanti (2012) dengan hasil 19,15\%.

Berat karkas akan mempengaruhi persentase karkas dan bagian-bagiannya. Bagian dada dan bagian paha berkembang lebih dominan selama pertumbuhan apabila dibandingkan pada bagian sayap (Abubakar dan Nataamijaya, 1999).

Persentase paha. Hasil analisis statistik, perlakuan pakan dengan enceng gondok terfermentasi tidak memberikan pengaruh terhadap persentase paha itik lokal. Rata-rata persentase paha masing-masing perlakuan $\mathrm{P} 0, \mathrm{P} 1, \mathrm{P} 2, \mathrm{P} 3$ dan P4 berturut-turut adalah 29,$11 ; 28,26 ; 29,41 ; 27,16$; dan $29,4 \%$.

Itik lokal jantan menghasilkan pertumbuhan dan persentase paha yang tidak berbeda nyata karena jenis kelamin, umur, dan genetik itik lokal jantan yang digunakan sama. Moran (1999) menyatakan bahwa pertumbuhan dipengaruhi oleh faktor genetik, jenis kelamin, umur, dan lingkungan. Soeparno (1988) menambahkan bahwa nutrien ransum mempengaruhi komponen tubuh secara sama kecuali lemak meskipun perlakuan nutrien berbeda, artinya faktor genetik sangat mempengaruhi pertumbuhan. Bagian paha merupakan bagian yang pertumbuhannya lebih awal daripada bagian lainnya (Swatland, 1984).

Persentase dada. Persentase dada itik pada pemotongan umur delapan minggu akibat pengaruh perlakuan pakan (P0, P1, P2, P3, dan P4) berturutturut adalah 20,$40 ; 20,55 ; 20,68 ; 20,12 ;$ dan $21,15 \%$.

Perlakuan pakan tidak memberikan pengaruh terhadap persentase dada itik. Bobot dada yang tinggi memungkinkan persentase karkas juga tinggi (Hadiwiyoto, 1992). Dada merupakan tempat deposisi daging, perlakuan pakan dengan penambahan enceng gondok terfermentasi taraf 2,5\% 
sampai $10 \%$ belum mampu meningkatkan persentase dada.

Moran (1999) menyatakan bahwa pertumbuhan dipengaruhi oleh faktor genetik, jenis kelamin, umur, dan lingkungan. Soeparno (1988) menambahkan bahwa nutrien ransum mempengaruhi komponen tubuh kecuali lemak, meskipun perlakuan nutrien berbeda-beda. Sel otot dada diduga sudah mencapai pertumbuhan maksimal sehingga penambahan enceng gondok terfermentasi tidak mempengaruhi persentase dada yang dihasilkan.

Persentase punggung. Berdasarkan hasil analisis, perlakuan pakan dengan enceng gondok fermentasi tidak memberikan pengaruh terhadap persentase punggung itik lokal yang dipotong pada umur delapan minggu. Rerata persentase punggung masing-masing perlakuan $\mathrm{P} 0, \mathrm{P} 1, \mathrm{P} 2, \mathrm{P} 3$, dan P4 berturut-turut adalah 24,$46 ; 25,36 ; 24,42 ; 24,79$; dan $24,52 \%$.

Punggung merupakan bagian yang didominasi oleh tulang dan kurang berpotensi menghasilkan daging. Selama pertumbuhan, tulang tumbuh secara terus-menerus dengan kadar laju pertumbuhan relatif lambat, sedangkan pertumbuhan otot relatif lebih cepat sehingga rasio otot dengan tulang meningkat selama pertumbuhan (Soeparno, 1994). Diduga penggunaan enceng gondok terfermentasi mulai $2,5 \%$ sampai $10 \%$ menghasilkan ketersediaan mineral dalam pakan yang relatif sama sehingga memberikan hasil pertumbuhan punggung yang sama pula.

\section{Persentase non-karkas}

Hasil analisis menunjukkan bahwa pakan dengan penggunaan enceng gondok terfermentasi sampai taraf $10 \%$ tidak memberikan pengaruh terhadap persentase non-karkas. Nilai rerata bobot kepala $15,22 \%$; kaki/shank 2,68\%; hati $2,21 \%$; jantung $0,72 \%$; dan empedal $4,74 \%$.

Itik lokal jantan menghasilkan kepala dan leher dalam persentase yang relatif sama karena secara genetik laju pertumbuhan kepala dan leher sama, tanpa dipengaruhi oleh ransum yang diberikan. Tillman et al. (1991) menyatakan bahwa kecepatan pertumbuhan dari tulang kepala dan kaki, panjang badan dan otot, bagian dalam badan dan lemak terlepas dari pengaruh pakan. Hal ini diduga karena komponen kaki sebagian besar terdiri dari tulang yang pertumbuhannya pada saat dewasa adalah konstan. Menurut Soeparno (1994) bahwa pertumbuhan komponen tubuh yaitu tulang pada saat mencapai kedewasaan hampir konstan. Ceker/shank juga organ yang didominasi tulang dan kulit, sehingga perbedaan perlakuan pakan tidak memberikan hasil yang berbeda. Rosyidi (2000) menyatakan bahwa perubahan berat kepala dan kaki terutama berhubungan dengan umur potong karena kedua organ ini kurang sensitif terhadap perlakuan pakan.

Giblet merupakan organ masak dini yang pertumbuhannya pada saat mencapai dewasa adalah konstan. Giblet termasuk organ masak dini yang esensial dalam kehidupan embrional (Prilyana, 1984) dan konstan setelah mencapai kedewasaan (Soeparno, 1994).

Hasil ini diduga karena selama periode pertumbuhan sampai menjelang dewasa, giblet telah mengalami pertumbuhan yang paling besar seawal mungkin dan mulai menurun menjelang dewasa sehingga dalam periode pertumbuhan ini pemberian nutrien yang berbeda, tidak berpengaruh terhadap pertumbuhannya. Pertumbuhan empedal juga sedikit sekali dipengaruhi oleh pakan. Hal ini sesuai dengan pendapat Lesson dan Summer (1980) bahwa organ yang penting untuk proses kehidupan tumbuh dahulu dan lebih cepat pada organ yang digunakan untuk produksi.

\section{Persentase lemak abdominal}

Pakan dengan tambahan enceng gondok terfermentasi sampai taraf $10 \%$ tidak berpengaruh terhadap lemak abdominal. Hasil penelitian masingmasing perlakuan $\mathrm{P} 0, \mathrm{P} 1, \mathrm{P} 2, \mathrm{P} 3$, dan $\mathrm{P} 4$ berturutturut yaitu 0,$59 ; 0,64 ; 0,60 ; 0,66$; dan $0,66 \%$.

Lemak abdominal dipengaruhi oleh pakan dan umur. Pakan yang digunakan dalam penelitian ini mempunyai imbangan energi protein yang setara yaitu 198 sampai 200, dan pemotongan itik pada umur yang sama yaitu delapan minggu, sehingga menghasilkan lemak abdominal yang relatif sama. Lemak abdominal akan meningkat seiring dengan meningkatnya umur itik. Penggunaan enceng gondok terfermentasi dari $2,5 \%$ sampai $10 \%$ tidak mempengaruhi ketersediaan energi untuk menghasilkan lemak abdominal yang berbeda. Menurut Anggorodi (1995) pertumbuhan jaringan lemak ditentukan oleh ada atau tidaknya energi hasil metabolisme yang berlebih di dalam tubuh. Persentase lemak hasil penelitian ini relatif lebih rendah dibandingkan hasil penelitian Ismoyowati (1999) yang melaporkan bahwa rata-rata lemak abdominal itik lokal 0,9\% dan penelitian Dewanti (2012) menghasilkan lemak abdominal $0,73 \%$. Sinurat et al. (1992) menyatakan bahwa persentase lemak abdominal sesuai dengan pola berat badan yaitu meningkatnya berat badan diikuti oleh peningkatan kandungan lemak abdominal.

\section{Kesimpulan}

Berdasarkan hasil penelitian dapat disimpulkan bahwa penggunaan enceng gondok terfermentasi dalam ransum sampai tingkat $10 \%$ 
belum meningkatkan bobot potong, persentase karkas, non-karkas, dan lemak abdominal itik lokal umur delapan minggu.

\section{Daftar Pustaka}

Abubakar dan A. G. Nataamijaya. 1999. Persentase karkas dan bagian-bagiannya dua galur ayam broiler dengan penambahan tepung kunyit (Curcuma domestica Val) dalam ransum. Buletin Peternakan. Edisi Tambahan: 174179.

Anggorodi. 1995. Nutrisi Aneka Ternak Unggas. P.T. Gramedia Pustaka Utama, Jakarta.

Bidura, I. G. N. G., N. L. G. Sumardani, T. Istri Putri, dan I. B. G. Partama. 2005. Pengaruh pemberian ransum terfermentasi terhadap pertambahan berat badan, karkas dan jumlah lemak abdomen pada itik bali. Jurnal Pengembangan Peternakan Tropis 33: 274281.

Deaton, J. W. and B. D. Lott. 1985. Age and dietary energy effect on broiler chicken. J. Poult. Sci. 70: $1550-1558$.

Dewanti, R. 2012. Pengaruh pejantan dan pakan terhadap karkas dan lemak abdominal itik turi umur delapan minggu. Prosiding Seminar Nasional Fakultas Agroindustri Universitas Mercu Buana, Yogyakarta.

Hadiwiyoto, S. 1992. Kimia dan Teknologi Daging Unggas. Pusat Antar Universitas Pangan dan Gizi. Universitas Gadjah Mada. Yogyakarta.

Ismoyowati. 1999. Pengaruh pejantan, induk, aras protein dan seks terhadap pertumbuhan dan karkas itik lokal. Tesis. Pascasarjana Peternakan Universitas Gadjah Mada. Yogyakarta.

Kamal, M. 1994. Nutrisi Ternak I Rangkuman. Lab Makanan Ternak. Jurusan Nutrisi dan Makanan Ternak. Fakultas Peternakan. Universitas Gadjah Mada. Yogyakarta.

Kamal, M. 1994. Pengaruh penambahan DLmethionin sintetis kristal ke dalam ransum fase akhir terhadap perlemakan tubuh ayam broiler. Buletin Peternakan 18: 40-46.

Lesson, S., L. Coston and J. D. Summer. 1980. Broiler response to energy and protein dilution in the finisher diet. J. Poult. Sci. 75: 522-528.

Mangisah, I., Tristiarti, W. Murningsih, M. H. Nasoetion, E. S. Jayanti, dan Y. Astuti. 2006. Kecernaan nutrien enceng gondok difermentasi Aspergillus niger dan pengaruhnya terhadap performan ayam broiler. Jurnal Pengembangan Peternakan Tropis 31: 124128.
Mangisah, I., B. Sukamto and M. H. Nasution. 2009. Implementation of fermented enceng gondok in duck ration. J. Ind. Trop. Anim. Agric. 34: 127-133.

Moran, E. T. 1999. Live Production Factors Influencing Yield and Quality of Poultry Meat Science. CAB International. England.

Prilyana, J. D. 1984. Pengaruh pembatasan pemberian jumlah ransum terhadap persentase karkas, lemak abdominal, lemak daging paha dan bagian-bagian giblet ayam pedaging. Karya Ilmiah. Fakultas Peternakan, Institut Pertanian Bogor. Bogor.

Rosyidi, D. 2000. Dampak docking dan tingkat konsentrat pada domba ekor gemuk terhadap bobot potong, persentase karkas dan persentase bagian tubuh non karkas. Jurnal Ilmiah Habitat 11: 122-127.

Sastrosupadi, A. 2000. Rancangan Percobaan Praktis Bidang Pertanian. Edisi Revisi. Kanisius. Yogyakarta.

Scott, M. L., Neaheim and R. J. Young. 1982. Nutrition of The Chicken. $2^{\text {nd }}$ ed. M. L Scott and Associate Ithaca, New York.

Sinurat, A. D., J. Bestari, Winarno, R. Martondang, P. Setiadi, dan S. Wahyuni. 1992. Pengaruh imbangan asam amino, energi metabolis ransum terhadap penampilan itik. Prosiding pengolahan dan komunikasi hasil-hasil penelitian unggas dan aneka ternak. Pusat Penelitian dan Pengembangan Peternakan, Ciawi. Bogor.

Sudiastra, I. W. 2001. Pengaruh penambahan efektif mikroorganisme dalam ransum berprotein rendah terhadap komposisi fisik karkas ayam jantan tipe petelur. Majalah Ilmiah Peternakan 4: 84-89.

Soeharsono. 1979. Pemanfaatan enceng gondok sebagai makanan ternak non ruminansia. Prosiding seminar dan Penelitian dan Penunjang Pengembangan Peternakan. Lembaga Penelitian Peternakan Badan Penelitian dan Pengembangan Pertanian Departemen Pertanian, Bogor 5-10 November.

Soeparno. 1988. Komposisi Kimia Daging. Gadjah Mada University Press. Yogyakarta.

Soeparno. 1994. Ilmu dan Teknologi Daging. Edisi Pertama. Gadjah Mada University Press. Yogyakarta.

Srigandono, B. 1997. Ilmu Unggas Air. Gadjah Mada University Press. Yogyakarta.

Swatland, H. J. 1984. Sructure and Development of Meat Animals. Prentice-Hall. Inc. Englewood Cliffs. New Jersey. 
Tillman, A. D., S. Reksohadiprojo, S. Prawirokusumo, S. Lebdosoekojo, dan H. Hartadi. 1991. Ilmu Makanan Ternak Dasar. Gadjah Mada University Press. Yogyakarta.
Wahyu, J. 1985. Ilmu Nutrisi Unggas. Gadjah Mada University Press. Yogyakarta.

Windhyarti, S. S. 2002. Beternak Itik Tanpa Air. Penebar Swadaya. Jakarta. 